\title{
PECULIARITIES OF DEVELOPMENT OF CORN EARWORM IN THE MAIZE AGROCENOSIS OF THE LEFT-BANK FOREST STEPPE OF UKRAINE
}

\author{
Yuliia Liaska ${ }^{1}$ \\ juljabug@ukr.net \\ Oleksandr Stryhun ${ }^{1}$ \\ strygun@meta.ua \\ ${ }^{1}$ Institute of Plant Protection of National Academy of Agrarian Sciences of Ukraine \\ 33 Vasylkivska str., Kyiv, Ukraine, 03022
}

\begin{abstract}
Biological features of the development of the corn earworm in Ukraine are insufficiently studied. Therefore, the research conducted in 2017-2019 were the first attempt to describe in detail the phenology of the pest in the maize agrocenosis of the Left Bank Forest-Steppe of Ukraine.

It was found, that the emergence duration of the corn earworm imagoes during the years of research lasted 46-52 days. The first butterflies on maize appeared in the first and third decades of June. The mass emergence of the phytophagous occurred in the second-third decade of July (the bloom period of maize). The seasonal dynamics of corn earworm imago in maize significantly depended on both the weather conditions of the growing seasons and the phases of crop development.

The duration of development of the stages of eggs, caterpillars and pupae in 2017-2019 was 5.3, 31 and 20 days, at the sum of effective temperatures of $38.5,243.6$ and $147.0^{\circ} \mathrm{C}$, accordingly.

In maize crops in the Left-Bank Forest-Steppe of Ukraine corn earworm developed during one generation, and the second generation was optional. Corn plants are damaged only by the first generation of phytophagous.

For the development of the first generation of phytophagous, the sum of effective temperatures must be $590-610{ }^{\circ} \mathrm{C}$ at the development threshold of $+15.0^{\circ} \mathrm{C}$, the duration of development is on average 61.3 days, at the average daily air temperature $+21.6^{\circ} \mathrm{C}$.

Keywords: corn earworm, phenology, generation, imago, caterpillars, pupae, sum of effective temperatures, maize crops.
\end{abstract}

DOI: $10.21303 / 2504-5695.2020 .001526$

\section{Introduction}

Maize crops in all climatic zones are damaged by numerous polyphagous and specialized pests throughout the growing season. One of the most dangerous phytophage is corn earworm (Helicoverpa armigera Hbn. series Lepidoptera, family Noctuidae).

Phytophagous caterpillars can feed on more than 120 species of plants. The main damaged crops are corn, sunflower, chickpeas, tomatoes, as well as alfalfa, soybeans and others [1].

In the forest-steppe of Ukraine corn earworm prefers primarily maize, which promotes the development of the most numerous and viable offspring. The caterpillars of corn earworm damage the pistil threads, grains, wrappers of cobs, roughly eating them. Damage by caterpillars of cobs and grains led to the development of pathogens, deterioration of crop quality, which further complicated the storage of grain. Therefore, damage to corn plants in the bloom phase and grain formation phase is the most dangerous [2-4].

Annual crop losses of products of cotton, corn, vegetables, legumes, etc. in the world because of corn earworm exceed $\$ 2$ billion, and the cost of protective measures is about 1 billion. In China and India, about $50 \%$ of all insecticides are used against the corn earworm. There farmers spend up to $40 \%$ of their income on insecticides to protect crops from this phytophagous. In the United States, the corn earworm is considered one of the most dangerous pests of agricultural plants [5].

Thus, the study of the peculiarities of the development of the corn earworm is the basis for predicting the number of phytophagous and carrying out reasonable measures to protect maize against this pest.

In Ukraine, the biological and ecological features of the development of the corn earworm in a particular area are insufficiently studied. So, Yu. V. Biliavskyi and others say about the pos- 
sibility of development from II to V generations of phytophagous in the Northern Forest-Steppe of Ukraine [6]. M.M. Dolya and others indicate the development of the second-third generation in the forest-steppe zone, and maize plants are damaged by caterpillars of second generation [7]. Yu. E. Klechkovskyi says about the possibility of development of third generations in the South [8]. Scientists from northern China point on the development of the fourth generation of the corn earworm, and the first generation develops on winter wheat [9].

Thus, this work is the first attempt to describe in detail the phenology of mass reproduction of phytophagous in the conditions of the Left Bank Forest-Steppe of Ukraine.

\section{Materials and Methods}

To study the emergence dynamics of butterflies, their number during critical periods of crop vegetation and their biological features, we carried out the constant monitoring of butterflies (every three days) using pheromone traps (3 pieces per field of 4-5 hectares). Phytophagous phenology was studied in the field conditions of the Cherkassy Research Station of Biological Resources of the NSC "Institute of Agriculture of NAAS" in 2017-2019 since the first decade of May till the third decade of October. Conventional methods of entomology were used to detect all phases of the pest in the field [10].

To determine the age-related changes in the molting process we sized the head capsule and the body length of the cotton earworm caterpillars using a digital microscope and a ruler.

The sum of effective temperatures (SET) and the hydrothermal coefficient (HTC) were used in the research. These indicators were determined by formulas (1) and (2) [11].

$$
S E T=\left(t_{a d t}-t_{b t t}\right) \times N,
$$

$t_{a d t}$ - average daily temperature, above the biological threshold $10^{\circ} \mathrm{C} ; t_{b t t}$ - biological threshold temperature; $N$ - number of days of the analyzed period.

$$
H T C=\frac{10 \sum R}{\mathrm{SAT}},
$$

$\Sigma R$ - the amount of precipitation for the analyzed period; $S A T$ - the sum of active temperatures above $10{ }^{\circ} \mathrm{C}$ during this period.

\section{Results and Discussion}

It was found, that the emergence of corn earworm butterflies begins when the soil at a depth of $10 \mathrm{~cm}$ warms up to $15-16^{\circ} \mathrm{C}$. In 2017-2019, the emergence of corn earworm butterflies was observed in the first - third decades of June (Fig. 1), but those were solitary individuals that rarely laid eggs on corn plants.

2017 was marked by the earliest beginning of the emergence of butterflies (7.06) (average 2.6 specimens per trap).

Emergence of imago was very uneven, so after departure 7.06 (2.6 specimens/trap), the number of males, trapped on the following days, decreased and in the third decade of June was 1.2 specimens/trap for 10 days. This is due to the insufficient amount of effective temperatures of this period. According to many researchers the optimal conditions for the development of the corn earworm - temperature $+20.0{ }^{\circ} \mathrm{C}-+30.0{ }^{\circ} \mathrm{C}$ and relative humidity of $60-80 \%$ [12-15].

With the accumulation of a sufficient amount of effective temperatures, the mass emergence of butterflies was observed since the end of the first decade of July ( 4.5 specimens/trap in 10 days). The peak number of males was observed in the second decade of July (15.9 specimens/trap in 10 days). Then the intensity of meteor use decreases. The peak number of corn earworm butterflies in 2017 coincided with the phase of blooming (13.07-15.07).

With a sharp rise of average daily temperature in the I-II decades of August to $+25.3^{\circ} \mathrm{C}$ (Fig. 2) (above the long-term norm by $+3.2^{\circ} \mathrm{C}$ ), and increasing of daytime temperatures up to $+37^{\circ} \mathrm{C}$ and a small amount of precipitation of about $20 \mathrm{~mm}$ in the third decade of August, second-generation corn earworms had appeared in pheromone traps $(\approx 3.8$ specimens per trap), but with a sharp decreasing of 
temperature at the end of the third decade of August to $+18.0^{\circ} \mathrm{C}$ and rain, the activity of butterflies had decreased significantly and, later until the second decade of October 0.3-2.2 males per trap per decade were observed in traps. There were also periods, when no butterflies were found in the traps.

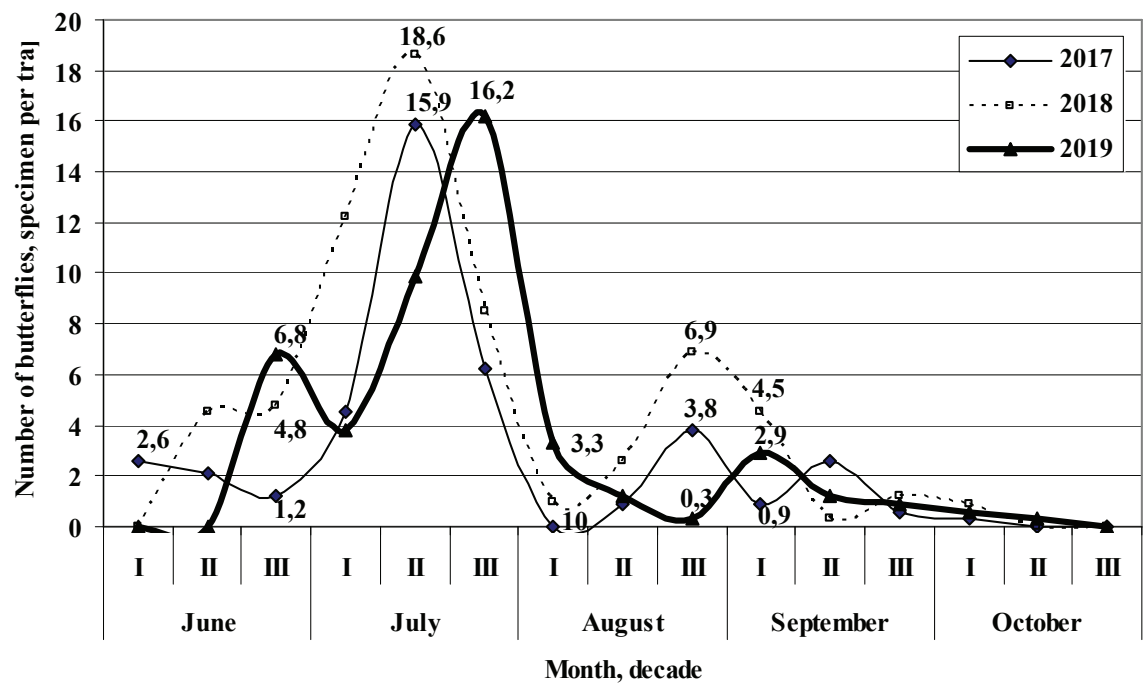

Fig. 1. Seasonal dynamics of the number of Helicoverpa armigera Hbn. imagoes in maize crops, 2017-2019

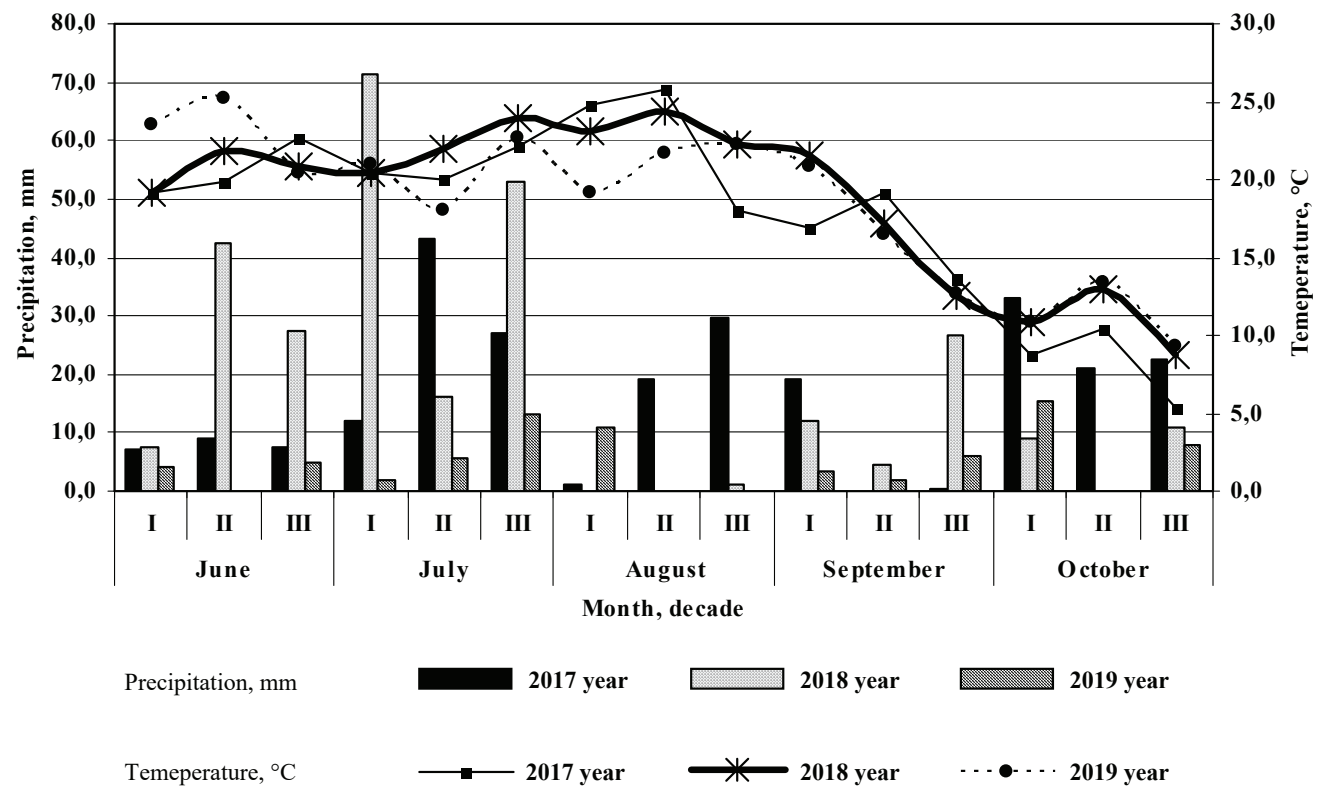

Fig. 2. Climatogram of weather conditions of Cherkassy research station of Biological Resources of NSC "Institute of Agriculture of NAAS", 2017-2019

In 2018, the emergence of butterflies Helicoverpa armigera Hbn. was 6 days later than last year. The third decade of May was without precipitation, daytime temperatures rose to $+28{ }^{\circ} \mathrm{C}$, and nighttime temperatures dropped to $+11^{\circ} \mathrm{C}$, which caused uneven warming of the soil. Such conditions restrained the development of pupae. As the average daily temperature increased to $+21.8^{\circ} \mathrm{C}$ in the second decade of June, the first males of the corn earworm appeared $(\approx 4.5$ specimens per trap in 10 days $)$. At the beginning of July there were heavy rains, the amount of precipitation was $71.5 \mathrm{~mm}$. Such conditions restrained the emergence and feeding of corn earworms imagoes. But at the end of the first decade of July the number of butterflies gradually increases, reaching its peak of 18.6 specimens per trap in the second decade of July (Fig. 1), which coincides with the phase of ejection of panicles and blooming. 
Since the end of the third decade of July, the emergence of butterflies has almost halved and later the intensity of emergence was weak. Since the end of the second decade of August, the activity of second-generation corn earworm butterflies (2.6 specimens per trap) was observed. Weather conditions in August contributed to the emergence of butterflies, as evidenced by their increase to 6.9 specimens per trap (III decade of August). With a decrease in air temperature in the second decade of September up to +17.2 , the emergence of butterflies decreases $(0.3$ specimens per trap).

In 2019, the emergence of males was the latest (21.06), but immediately the most intense 6.8 specimens per trap at the average daily air temperature of $+25.2^{\circ} \mathrm{C}$ (Fig. 1). In the first decade of July, the emergence of butterflies decreases slightly to 3.8 specimens per trap, due to lower average daily air temperatures and no precipitation in June. At the beginning of the second decade of July the activity of butterflies was low, because the average daily air temperature decreased to $+18.0^{\circ} \mathrm{C}$, but since the end of the second decade of July, with a gradual increase in temperature, the emergence resumes and (5.3 specimens per trap in three days) and in the third decade of July reaches a peak (16.2 specimens per trap in 10 days). The mass emergence of imagoes in 2019 also clearly coincides with the bloom period of maize (July 21-July 23). Then the intensity of emergence of butterflies decreases sharply. August 2019 was arid, and the average daily temperature was $+21.0^{\circ} \mathrm{C}$ (deviation from the norm was $-0.2^{\circ} \mathrm{C}$ ). Under such conditions in the first decade of September there was a single emergence of second-generation butterflies (2.9 specimens/trap). During a sharp cold snap in the second decade of September, the activity of butterflies ceased, during warm and rainless October, single male specimen were found in traps.

Due to the fact that among wintering pupae there are diapause and non-diapause ones, with different diapause periods, the emergence of first-generation butterflies is very lengthy. It also depends on the weather conditions, so excessive precipitation greatly extended the period of imago regeneration. The duration of emergence of first-generation butterflies is 45-65 days, and most of butterflies emerge within 10-15 days [16], which coincides with our research.

Thus, according to the results of 2017-2019, the emergence of first-generation imagoes in 2017 was 52 days, in 2018 - 55 and in 2019 - 46 days. The first butterflies on maize appear in the I-III decades of June at an average daily air temperature of $+19.1 \ldots+21.8^{\circ} \mathrm{C}$ and humidity of 63-75\%. The mass emergence of the phytophage occurred in the second decade of July in 2017 and 2018 and in the third decade of July in 2019. The seasonal dynamics of the number of imagoes significantly depends on both weather conditions and the phase of crop development. During 2017, 41.6 were caught specimens per trap, in 2018 - 66.0 and in $2019-47.4$ specimens per trap.

Influence of abiotic factors on the development of corn earworm. The population density of the corn earworm largely depends on environmental conditions.

According to the observations on the phenology of phytophagous in 2017 (Fig. 3) the emergence of the first butterflies was detected at the end of first decade of June, since the beginning of the third decade of June the average daily air temperature began to rise sharply up to $+22.7^{\circ} \mathrm{C}$ and the amount of precipitation in June was $23.5 \mathrm{~mm}$. The period of mass emergence of butterflies of first-generation was observed since the beginning of the second decade of July till the end of the third decade, and therefore the bulk of imagoes emerged in 16 days. The first egg-laying on maize was observed in early July (26 days after the beginning of emerging).

The whole period of egg-laying lasted about 25-27 days since the first decade of July till the first decade of August at the average daily air temperature of $+21.8{ }^{\circ} \mathrm{C}$ and the small amount of precipitation of $83.2 \mathrm{~mm}$. The main mass of eggs was observed during the mass emerging (since 16.07-28.07) and lasted for about 14-16 days.

The appearance of the first caterpillars was observed at the end of the first decade of July (panicle flowering phase) at the average daily air temperature of $+20.4{ }^{\circ} \mathrm{C}$ and the precipitation of $12.0 \mathrm{~mm}, 8$ days after the beginning of egg-laying. The first half of the second decade of July was rainy $(43.2 \mathrm{~mm})$, so the mass revival of caterpillars began at the end of the second decade of July, which coincided with the period of formation of corn grain. The average daily temperature of this period was $+22.7^{\circ} \mathrm{C}$, and the amount of precipitation was $27.0 \mathrm{~mm}$. The whole period of development of first-generation caterpillars lasted for 23-25 days. The availability of sufficient fodder base and favorable weather conditions for development allowed the caterpillars to go through six generations, accumulate enough nutrients and go to pupation, which began in the beginning of second decade of 
August. Most of the first-generation caterpillars that hatched remained for wintering. The first half of August was the hottest, the average daily temperature was $+25.3^{\circ} \mathrm{C}$, and the amount of precipitation was $20.0 \mathrm{~mm}$, which had a positive effect on the development of pupae and at the end of the third decade of August the appearance of second generation butterflies was noted.

The first eggs of the new generation on maize plants were detected in the second decade of September. In the first decade of September, the average daily air temperature decreased sharply to $+16.9^{\circ} \mathrm{C}$, so the embryonic period was quite long. In the second decade of September, the average daily air temperature increased slightly to $+19.2^{\circ} \mathrm{C}$ but there was no precipitation. So, at the beginning of the third decade of September there were a small number of second-generation caterpillars of the corn earworm. Feeding was not observed and weather conditions in September were unfavorable for the growth and development of caterpillars, so the second-year caterpillars did not hatch.

Due to the warm May and sharp warming in the second decade of June (up to $+21.8^{\circ} \mathrm{C}$ ) in 2018 butterflies began to revive intensively, but due to excessive rainfall in the end of second decade of June $(42.5 \mathrm{~mm})$ and in the first decade of July $(71.5 \mathrm{~mm})$ the emergence of butterflies was strongly extended, and lasted for 25 days (since the end of the first decade of July till the first decade of August) which was 10 days longer than previous year (Fig. 4).

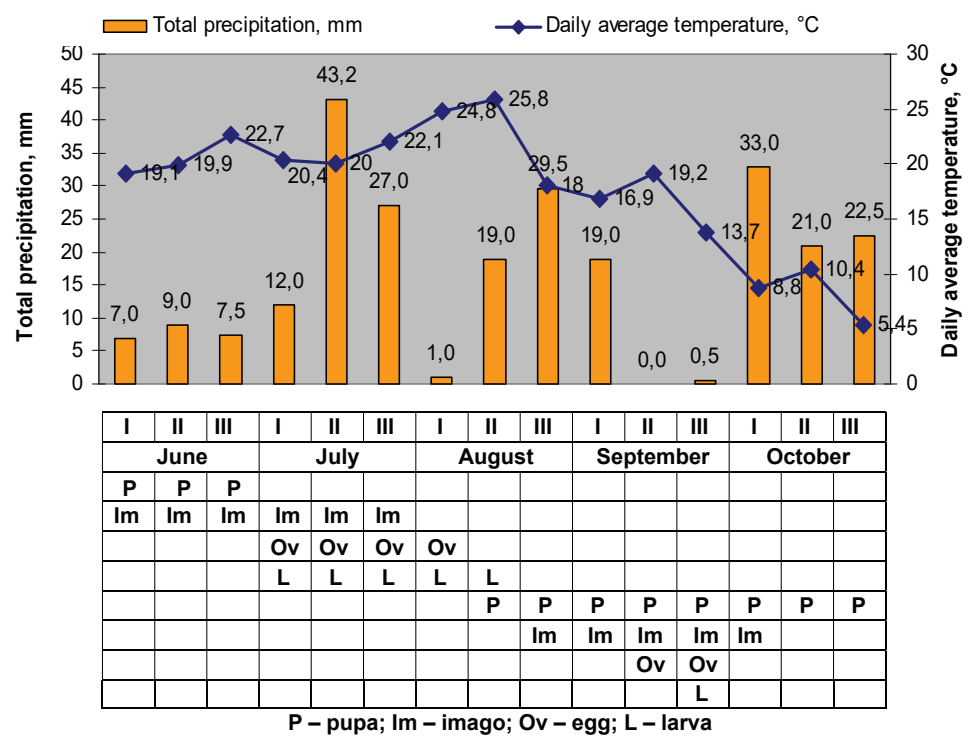

Fig. 3 Phenoclimate diagram of the development of corn earworm in maize crops, 2017

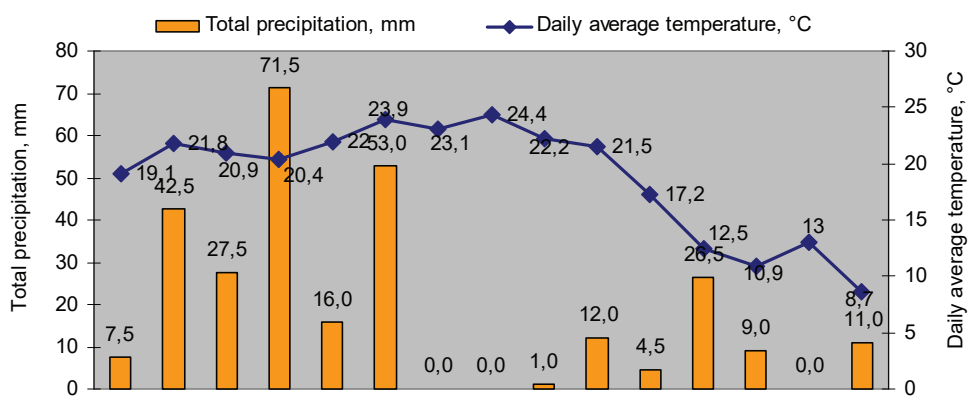

\begin{tabular}{|c|c|c|c|c|c|c|c|c|c|c|c|c|c|c|c|c|c|c|}
\hline I & II & III & I & II & III & I & II & III & I & II & III & I & II & III \\
\hline \multicolumn{3}{|c|}{ June } & \multicolumn{3}{|c|}{ July } & \multicolumn{5}{|c|}{ August } & \multicolumn{3}{|c|}{ September } & \multicolumn{3}{|c|}{ October } \\
\hline P & P & P & & & & & & & & & & & & \\
\hline & Im & Im & Im & Im & Im & Im & & & & & & & & \\
\hline & & Ov & Ov & Ov & Ov & Ov & & & & & & & & \\
\hline & & L & L & L & L & L & & & & & & & & \\
\hline & & & & & & P & P & P & P & P & P & P & P & P \\
\hline & & & & & & & Im & Im & Im & Im & Im & Im & & \\
\hline & & & & & & & & Ov & Ov & Ov & & & & \\
\hline & & & & & & & & & L & L & L & & & \\
\hline
\end{tabular}

Fig. 4 Phenoclimate diagram of the development of the corn earworm in corn crops, 2018 
The first eggs of females were laid in the third decade of June, at the average daily air temperature of $+20.9{ }^{\circ} \mathrm{C}$ and the precipitation of $27.5 \mathrm{~mm}$. The period between since the beginning of emergence of butterflies and till the emergence of egg lasted 14 days. The period of egg-laying in 2018 was longer and lasted about 30-32 days at the average daily temperature of $+22.0^{\circ} \mathrm{C}$ and the precipitation of $168 \mathrm{~mm}$. Mass egg-laying was observed during the period of mass emergence of butterflies, which coincided with the bloom phase of corn.

The first caterpillars began to appear on maize plants in the end of third decade of June after 6 days the egg-laying. Since the middle of the second decade of July till the end of the third decade caterpillars begin to regenerate en masse. In the presence of sufficient fodder base and average daily air temperature of $+23.0^{\circ} \mathrm{C}$ and the amount of precipitation $69 \mathrm{~mm}$, the duration of caterpillar development was 30-32 days.

The third decade of July was excessively humid (53.0 $\mathrm{mm}$ of precipitation) and there was in August no precipitation and the average daily temperature was $+23.2{ }^{\circ} \mathrm{C}$.

Such weather conditions were favorable for the development of pupae and at the end of the second decade of August second-generation butterflies began to appear. At the end of the third decade of August, the appearance of the first eggs of the phytophage was observed, and the caterpillars began to regenerate in early September at the average daily air temperature of $+21.5^{\circ} \mathrm{C}$ and a precipitation of $12 \mathrm{~mm}$. With the decrease in air temperature in the second decade of September $\left(+17.2^{\circ} \mathrm{C}\right)$ second-generation caterpillars did not have time to go through all phases of development and go to pupation. The solitary emergency of butterflies lasted until the end of the first decade of October, but the eggs on maize plants were not laid. It is necessary to note, that butterflies of corn earworm are considered nocturnal insects, but since the end of August till October they flew also in the afternoon.

In 2019 May was cool and excessively humid, the average daily temperature was $+17.8^{\circ} \mathrm{C}$, and the amount of precipitation was $92 \mathrm{~mm}$ (166.4\% of the norm). Such conditions were unfavorable for the completion of pupae development, and the emergence of butterflies began later than in 2017-2018 (since the beginning of the third decade of June) at the average daily air temperature of $+25.2^{\circ} \mathrm{C}$ and no precipitation (Fig. 5). With the decrease of the average daily temperature in the second half of the third decade of June up to $+20.4{ }^{\circ} \mathrm{C}$ and the dry period of June-July $-20.5 \mathrm{~mm}$ ( $23 \%$ of the long-term norm), the mass emergence of butterflies was observed 10-12 days later than in previous years, and lasted since the end of the second decade of July till the first decade of August ( $\approx 19$ days) with the average daily temperature of $+20.0^{\circ} \mathrm{C}$ and the precipitation of $24 \mathrm{~mm}$. But the bulk of butterflies emerged in the third decade of July, when the average daily temperature was more optimal $\left(+22.7^{\circ} \mathrm{C}\right)$.

The first eggs on maize plants were detected in the end of third decade of June (10-11 days after the emergence of butterflies). The whole egg-laying period was longer than in 2017-2018 and lasted for about 35 days. Mass egg-laying was also observed later than in previous years (by 6-10 days) since the beginning of the third decade of July till the first decade of August at the average daily temperature of $+21.0^{\circ} \mathrm{C}$ and the precipitation of $12 \mathrm{~mm}$.

The first caterpillars began to appear in the first decade of July at the air temperature of $+21.0^{\circ} \mathrm{C}$ and the low humidity of $59 \%$. Under such conditions the development of caterpillars was delayed and mass revival was observed since the third decade of July till the second decade of August. The duration of caterpillar development lasted about 35 days at the average daily temperature of $+20.9^{\circ} \mathrm{C}$ and insufficient rainfall $-24 \mathrm{~mm}$.

Taking into consideration that most of caterpillars pupated later than in previous years - in the beginning of the third decade of August, and that during the second and third decades of August were no precipitation, the caterpillars had no time for pupation, so in the first decade of September a slight emergence was observed. Since the second decade of September the average daily temperature decreased sharply $\left(+16.5^{\circ} \mathrm{C}\right)$ and there were no feeding conditions, so no eggs or caterpillars were detected. The first and second decades of October were quite warm $\left(+12.5^{\circ} \mathrm{C}\right)$ and rainless, so the butterflies of the corn earworm were periodically trapped until the second decade of October.

Thus, the development of the corn earworm significantly depends on abiotic factors. Thereby, mass emergence and egg-laying was observed at an average daily temperature of $+21.0 \ldots+22.7^{\circ} \mathrm{C}$ and lasted 16-25 days. The first eggs were laid on 11-26 days after the emergence of the first imagoes, but this indicates that butterflies need additional nutrition for the reproduction. Average daily temperatures 
of $+22.7 \ldots+23.0^{\circ} \mathrm{C}$ and humidity of $65-75 \%$ are optimal for the development of the caterpillar. Decreasing of temperature up to $+20.0^{\circ} \mathrm{C}$ and the absence or excess of rainfall greatly extend the period of development of the caterpillar, which can last more than 30 days.

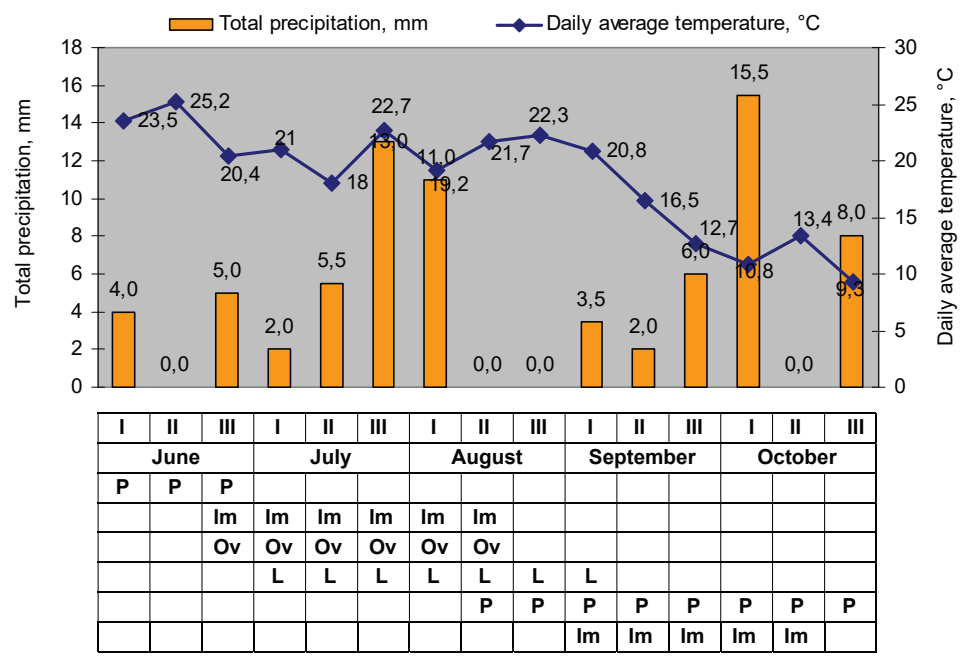

Fig. 5. Phenoclimate diagram of the development of the corn earworm in maize crops, 2019

Approximate hydrometric indices of phytophage development in the conditions of the Left-Bank Forest-Steppe of Ukraine were calculated on the basis of observations on the phenology of the corn earworm in 2017-2019 (Table 1).

Table 1

Development of corn earworm depending on the conditions of the growing season, 2017-2019

\begin{tabular}{|c|c|c|c|c|c|c|c|}
\hline \multirow[b]{2}{*}{ years } & \multicolumn{7}{|c|}{ Periods } \\
\hline & $\begin{array}{l}\text { until mass emer- } \\
\text { gence of imagoes }\end{array}$ & $\begin{array}{l}\text { mass emer- } \\
\text { gence }\end{array}$ & $\begin{array}{l}\text { butterflies } \\
\text { egg-laying }\end{array}$ & $\begin{array}{l}\text { egg-cater- } \\
\text { pillar }\end{array}$ & $\begin{array}{l}\text { development of } \\
\text { caterpillars }\end{array}$ & $\begin{array}{l}\text { pupae - caterpillars } \\
\text { of second generation }\end{array}$ & $\begin{array}{l}\text { full cycle of } \\
\text { development }\end{array}$ \\
\hline \multicolumn{8}{|c|}{ Daily average temperature, ${ }^{\circ} \mathbf{C}$} \\
\hline 2017 & 20.1 & 21.5 & 20.0 & 21.0 & 24.2 & 21.9 & 21.5 \\
\hline 2018 & 20.3 & 22.3 & 21.2 & 22.0 & 23.4 & 23.8 & 22.2 \\
\hline 2019 & 21.2 & 20.0 & 20.4 & 22.7 & 21.5 & 21.6 & 21.2 \\
\hline average & 20.5 & 21.3 & 20.5 & 21.9 & 23.0 & 22.4 & 21.6 \\
\hline \multicolumn{8}{|c|}{ Precipitations, $\mathrm{mm}$} \\
\hline 2017 & 55.5 & & & 0.2 & & 48.5 & 194.2 \\
\hline 2018 & 185.0 & & & 9.0 & & 0.0 & 254.0 \\
\hline 2019 & 103.0 & & & 9.5 & & 3.5 & 136.0 \\
\hline average & 114.5 & & & 2.9 & & 17.3 & 194.7 \\
\hline \multicolumn{8}{|c|}{ SET, ${ }^{\circ} \mathbf{C}$} \\
\hline 2017 & 275.0 & - & 30.0 & 41.3 & 248.3 & 141.0 & 594.6 \\
\hline 2018 & 371.6 & - & 28.0 & 35.0 & 253.9 & 142.6 & 688.5 \\
\hline 2019 & 300.2 & - & 24.4 & 38.5 & 228.6 & 157.4 & 591.7 \\
\hline average & 315.6 & - & 27.5 & 38.2 & 243.6 & 147.0 & 624.9 \\
\hline \multicolumn{8}{|c|}{ HTC } \\
\hline 2017 & 0.50 & \multicolumn{4}{|c|}{1.00} & 1.1 & 0.77 \\
\hline 2018 & 1.16 & \multicolumn{4}{|c|}{0.91} & 0 & 1.00 \\
\hline 2019 & 0.88 & \multicolumn{4}{|c|}{0.35} & 0.08 & 0.68 \\
\hline average & 0.85 & & & & & 0.39 & 0.82 \\
\hline \multicolumn{8}{|c|}{ Duration, days } \\
\hline 2017 & - & 16 & 6 & 6 & 26 & $20-22$ & 58 \\
\hline 2018 & - & 25 & 4 & 5 & 32 & 16 & 57 \\
\hline 2019 & - & 19 & 5 & 5 & 36 & 23 & 69 \\
\hline average & - & 20.0 & 5 & 5.3 & 31.0 & 20.0 & 61.3 \\
\hline
\end{tabular}


Thus, the sum of effective temperatures for the development of pupae and imagoes is $315.6^{\circ} \mathrm{C}$, which coincides with many scientific studies $[17,18]$. The sum of effective temperatures of $38.2^{\circ} \mathrm{C}$ is required for embryonic development. Optimal temperatures for the development of the caterpillar is $\approx 24.0^{\circ} \mathrm{C}$ and above and humidity is $65 \%$. At lower temperatures, the duration of caterpillar development increases. Similarly excessive humidity inhibits the growth of caterpillars. Thus, in 2018 during the third decade of July was $53 \mathrm{~mm}$ of precipitation, humidity was $85 \%$, average daily temperature was $+23.4^{\circ} \mathrm{C}$ and duration of the caterpillar phase was 32 . In 2019 at low temperatures $+21.5^{\circ} \mathrm{C}$ the duration of development was 36 days, in 2017 at the average daily temperature of $+24.2{ }^{\circ} \mathrm{C}$ and humidity of $67 \%$ the caterpillar phase lasted 26 days.

The sum of effective temperatures for the development of caterpillars under the conditions of sufficient feeding was $243.6^{\circ} \mathrm{C}$, and $147.0^{\circ} \mathrm{C}$ - for the development of pupae. The sum of effective temperatures of $590-610^{\circ} \mathrm{C}$ at the development threshold of $+15.0^{\circ} \mathrm{C}$ is required for the development of one generation.

It was established, that on maize crops in the Left-Bank Forest-Steppe of Ukraine the corn earworm develops in one generation and the second generation is optional. Maize plants are damaged only by the first generation of phytophagous.

Observations, conducted in 2017-2019, showed that the timing of the emergence of eggs and caterpillars on maize crops varied over the years, but always coincided with the bloom phase and the phase of grain formation.

It should be noted, that over the years of research of corn earworm caterpillars were detected on such cultivated plants as soybeans, sunflowers, chickpeas, tomatoes, as well as on such weeds as Convolvulus arvensis, Ambrosia artemisiifolia, Abutilon theophrasti and amaranth.

Study limitation. The difficulty was that in the field it is impossible to accurately determine the minimum threshold of $H$. armigera development $\left({ }^{\circ} \mathrm{C}\right)$, and in conventional methods, different data were given. In addition, due to the uneven number of pests over the years, it is advisable to conduct more long-term research.

Also an important limitation is the lack of own laboratory research on the biology of the development of the corn earworm.

Prospects for further research. To clarify the development threshold of the corn earworm, we plan to conduct laboratory studies on the biology of its development in the future.

The prospect of further research is the introduction into production of recommendations for single spraying of insecticides against the first generation of $H$. armigera caterpillars, which will reduce the pesticide load on the agrocenosis and save money and resources for protective measures.

Given the rapid trend of increasing average annual air temperature, it is advisable to continue research on the biology, ecology and phenology of pest development.

\section{Conclusions}

1. Depending on weather conditions in the Left-Bank Forest-Steppe of Ukraine the emergence of corn earworm butterflies begins in the I-III decades of June at an average daily temperature of $+19.1 \ldots+21.8^{\circ} \mathrm{C}$ and humidity of $63-75 \%$. It lasts $46-55$ days. The bulk of butterflies emerge in 16-25 days, which coincides with the bloom phase of maize. Mass emerging of butterflies and egg-laying took place at average daily temperatures of $+20.0 \ldots+21.2{ }^{\circ} \mathrm{C}$.

2. The duration of development of the stages of eggs, caterpillars and pupae in 20172019 was 5.3, 31 and 20 days for the sum of effective temperatures of $38.5,243.6$ and $147.0^{\circ} \mathrm{C}$ respectively.

3. Maize plants are damaged by first-generation caterpillars of the corn earworm, their largest number occurs in the third decade of July and the first decade of August, maize plants are in the phase of milk-wax ripeness of grain, so damage during this period is most dangerous.

4. For the development of the first generation of phytophage the sum of effective temperatures of $590-610{ }^{\circ} \mathrm{C}$ is required at the development threshold of $+15.0{ }^{\circ} \mathrm{C}$. The average duration of development over the years of research was 61.3 days at the average daily temperature of $+21.6{ }^{\circ} \mathrm{C}$. 
5. In the conditions of the Left-Bank Forest-Steppe of Ukraine the corn earworm develops in one generation. Most of the caterpillars of the first generation stay for the wintering after hatching, the second generation is optional.

\section{Conflict of interest}

There is no competing in the article.

\section{References}

[1] Voloshina, L. I., Terkovnaia, V. S. (2019). Cotton bollworm (Helicoverpa armigera) - pest of agriculture crops in transnistria. Agrarian Science, 326 (2), 119-121. doi: http://doi.org/10.32634/0869-8155-2019-326-2-119-121

[2] Cherkashin, V. N., Malyhina, A. N., Cherkashin, G. V. (2014). Cotton bollworm on field cultures. Zemledelie, 5, 35-36. Available at: http://jurzemledelie.ru/arkhiv-nomerov/5-2014/632-khlopkovaya-sovka-na-polevykh-kulturakh

[3] Gomes, E. S., Santos, V., Ávila, C. J. (2017). Biology and fertility life table of Helicoverpa armigera (Lepidoptera: Noctuidae) in different hosts. Entomological Science, 20 (1), 419-426. doi: http://doi.org/10.1111/ens.12267

[4] Trepashko, L. I., Nadtochaeva, S. V., Golovach, V. V. (2012). Opasnye vrediteli kukuruzy. Zashchita i karantin rastenii, 9, 18-20. Avaialble at: http://cyberleninka.ru/article/n/opasnye-vrediteli-kukuruzy-1

[5] Frolov, A. N. (2018). Nemnogo o hlopkovoi sovke i gm-kukuruze. Saint Petersburg-Pushkin: VIZIR. Available at: https://kosmais.narod.ru/downloads/frolov_sovka_gmo_2018.pdf

[6] Biliavskyi, Yu. V., Vusatyi, R. O. (2008). Uvaha: bavovnykova sovka. Vplyv zminy klimatu na poshyrennia ta shkidlyvist fitofaha v posivakh kukurudzy. Karantyn i zakhyst roslyn, 6, 2-4. Available at: http://base.dnsgb.com.ua/files/journal/ Karantyn-i-zahyst-roslyn/KiZR2008-6/KiZR2008-6_2-4.pdf

[7] Dolya, M., Fokin, A., Varchenko, T., Moroz, S. (2018). The trophic communication of the cotton bollworm in the modern growing technology of sunflower and corn in the Forest-Steppe of Ukraine. Naukovi dopovidi Natsionalnoho universytetu bioresursiv i pryrodokorystuvannia Ukrainy, 5 (75). doi: http://doi.org/10.31548/dopovidi2018.05.018

[8] Klechkovskyi, Yu. E., Hlushkova, S. O., Mohyliuk, N. T., Ihnatieva, O. V. (2017). Shkidlyvist populiatsii bavovnykovoi sovky ta mikrobiokontrol yii chyselnosti na posivakh tomativ. Ahrobiolohiia, 1, 141-146. Available at: https://agrobiologiya.btsau.edu.ua/ uk/content/shkidlyvist-populyaciyi-bavovnykovoyi-sovky-ta-mikrobiokontrol-yiyi-chyselnosti-na-posivah

[9] Wu, K.-M., Lu, Y.-H., Feng, H.-Q., Jiang, Y.-Y., Zhao, J.-Z. (2008). Suppression of Cotton Bollworm in Multiple Crops in China in Areas with Bt Toxin-Containing Cotton. Science, 321 (5896), 1676-1678. doi: http://doi.org/10.1126/science.1160550

[10] Dovhan, S. V., Dolia, M. M., Borzykh, O. I., Moroz, M. S., Yushchenko, L. P. (2014). Monitorynh shkidnykiv silskohospodarskykh kultur. Kyiv: Ahroosvita, 279.

[11] Trybel, S. O., Siharova, D. D., Sekun, M. P., Ivashchenko, O. O. et. al. Trybel, S. O. (Ed.) (2001). Metodyky vyprobuvannia i zastosuvannia pestytsydiv. Kyiv: Svit, 437. Available at: https://www.studmed.ru/tribel-s-o-s-garova-d-d-metodiki-viprobuvannya-zastosuvannya-pesticid-v_d39b8dcb768.html

[12] Bartekova, A., Praslicka, J. (2010). The effect of ambient temperature on the development of cotton bollworm (Helicoverpa armigera Hübner, 1808). Plant Protection Science, 42 (4), 135-138. doi: http://doi.org/10.17221/2768-pps

[13] Hao, L. (1998). Ehkologiya i prognoz poyavleniya hlopkovoi sovki v severo-zapadnom Kitae. Izvestiia Kharkovskogo entomologicheskogo obschestva. 2 (6), 147-149.

[14] Mironidis, G. K., Savopoulou-Soultani, M. (2011). Effects of thermophotoperiod on growth parameters of Helicoverpa armigera. Entomologia Experimentalis et Applicata, 142 (1), 60-70. doi: http://doi.org/10.1111/j.1570-7458.2011.01201.x

[15] Singh, S. (2017). Taxonomy and biology of Helicoverpa Armigera. International Journal of Global Science Research, 4 (2). doi: http://doi.org/10.26540/ijgsr.v4.i2.2017.85

[16] Ramazanova, Z. M. (2015). Ehkologo-troficheskii analiz fauny mnogoyadnyh sovok na ovoshchnyh kul'turah v Dagestane i razrabotka ehkologicheski bezopasnyh sposobov zashchity. Moskow, 152. Available at: https://www.elibrary.ru/item.asp?id=28849486

[17] Kuz'minskii, A. V., Fedorenko, V. P. (2014). Osobennosti razvitiya hlopkovoi sovki v severnoi Stepi Ukrainy. Zashchita i karantin rastenii, 11, 36-38. Available at: http://cyberleninka.ru/article/n/osobennosti-razvitiya-hlopkovoy-sovki-v-severnoy-stepi-ukrainy

[18] Misrieva, B. U., Ramazanova, Z. M., Misriev, A. M. (2017). Morfologicheskoe opisanie i osobennosti razvitiya Helicoverpa armigera HBN. v usloviyah Dagestana. Vestnik Socialno-pedagogicheskogo instituta, 1 (21), 16-23. Available at: http://spi-vuz.ru/ common/nauka/Vestnik_1(21)_2017.pdf 